\title{
Penanda Dan Fungsi Kesantunan Berbahasa Dalam Berwirausaha Di Media Sosial
}

\author{
Maulina Hendrik ${ }^{*}$, Diana Pramesti ${ }^{2}$ \\ ${ }^{1}$ Universitas Muhammadiyah Bangka Belitung, Bangka Tengah, Indonesia \\ 2 Universitas Muhammadiyah Bangka Belitung, Bangka Tengah, Indonesia \\ *Corresponding author: maulina.hendrik@unmuhbabel.ac.id
}

\begin{abstract}
This research background by Entrepreneurship learning which is done virtually or online. It is hoped that the learning outcomes of these courses will enable students to create a virtual business by utilizing social media. Cooperation and communication are competencies that are expected in virtual entrepreneurship. In order to establish good cooperation requires good communication skills as well. Therefore, this study aims to describe: 1) markers of politeness in the language of PGSD students on social media in entrepreneurship; 2) the function of language politeness based on the entrepreneurial context of PGSD students on social media. This study uses descriptive qualitative research methods. The source of this research data is the track record of learning outcomes for the odd semester Entrepreneurship course for the 2020/2021 academic year in the form of PGSD student utterances found on Whatsapp, Instagram. Data collection techniques using interview techniques and note-taking techniques. The data analysis technique used descriptive qualitative analysis. Based on the results of the analysis, it was found: 1) there are four markers of language politeness in the context of entrepreneurship in PGSD students' social media, namely choosing words according to the situation and conditions, responding humbly to comments from speech partners, positive responses to speech partners, receiving input from speech partners. speech partner; 2) there are three functions of language politeness in PGSD student conversations in entrepreneurship, namely stating information, asking, and agreeing.
\end{abstract}

Keywords: language politeness function; language politeness marker

\section{ABSTRAK}

Penelitian ini dilatarbelakangi oleh pembelajaran Kewirausahaan yang dilakukan secara virtual atau daring. Capaian pembelajaran matakuliah tersebut diharapkan mahasiswa mampu membuat sebuah usaha yang dilakukan secara virtual dengan memanfaatkan media sosial. Kerja sama dan berkomunikasi merupakan kompetensi yang diharapkan dalam berwirausaha secara virtual. Agar terjalin kerja sama yang baik dibutuhkan kemampuan berkomunikasi yang baik pula. Oleh karena itu, penelitian ini bertujuan untuk mendeskripsikan: 1) penanda kesantunan berbahasa mahasiswa PGSD di media sosial dalam berwirausaha; 2) fungsi kesantunan berbahasa berdasarkan konteks berwirausaha mahasiswa PGSD di media sosial. Penelitian ini menggunakan metode penelitian kualitatif deskriptif. Sumber data penelitian ini merupakan rekam jejak hasil pembelajaran mata kuliah Kewirausahaan semester ganjil tahun akademik 2020/2021 berupa tuturan-tuturan mahasiswa PGSD yang terdapat pada Whatsapp, Instagram. Teknik pengumpulan data menggunakan teknik wawancara dan teknik catat. Teknik analisis data menggunakan analisis deskriptif kualitatif. Berdasarkan hasil analisis, ditemukan: 1) terdapat empat penanda kesantunan berbahasa pada konteks berwirausaha di media sosial mahasiswa PGSD, yaitu pemilihan kata sesuai dengan situasi dan kondisi, menanggapi komentar dari mitra tutur dengan rendah hati, respons yang positif terhadap mitra tutur, menerima masukan dari mitra tutur; 2) terdapat tiga fungsi kesantunan berbahasa pada percakapan mahasiswa PGSD dalam berwirausaha, yaitu menyatakan informasi, menanyakan, dan persetujuan.

Kata Kunci: fungsi kesantunan berbahasa; penanda kesantunan berbahasa 


\section{Pendahuluan}

Hadirnya era revolusi industri 4.0 telah mempengaruhi proses belajar di ruang kelas. Zaman yang disebut sebagai zamannya teknologi informasi telah membuat pembelajaran dapat dilakukan di mana saja. Perkembangan Teknologi informasi dan komunikasi (TIK) di dunia pendidikan telah menggeser pembelajaran konvensional secara tatap muka ke arah pembelajaran jarak jauh yang dapat diakses dengan menggunakan media seperti komputer, multimedia, dan internet tanpa dibatasi jarak, tempat, dan waktu oleh siapa pun yang memerlukannya (Yaumi, 2018).

Muhadjir Effendy saat menyampaikan pidato pada kegiatan Hardiknas 2 Mei 2018 di Universitas Negeri Yogyakarta mengatakan perlu merevisi kurikulum menyesuaikan perkembangan zaman saat ini atau disebut dengan pembelajaran Abad 21. Kurikulum sebelumnya perlu ditambahkan 4 kompetensi, yaitu berpikir kritis, peserta didik memiliki kreativitas dan inovatif, mampu berkomunikasi, dan mampu bekerja sama atau berkolaborasi. Penyesuaian kurikulum abad 20 ke abad 21 diperuntukkan bagi calon lulusan agar dapat diserap oleh dunia kerja nantinya. Hal ini menjadi tantangan besar bagi pemerintah Indonesia dalam mengupayakan lulusan perguruan tinggi sesuai dengan kompetensi yang dibutuhkan oleh dunia kerja. Masalahnya hingga saat ini tingkat pengangguran di Indonesia semakin meningkat ditambah lagi sejak hadirnya pandemi Covid-19 yang menjadikan Indonesia mengalami krisis kesehatan dan lapangan pekerjaan semakin sulit didapatkan (M Hendrik \& Pramesti, 2021).

Kementerian Pendidikan dan Kebudayaan RI telah merancang pembelajaran yang dapat mengintegrasikan antara dunia pendidikan dengan dunia industri melalui program "Merdeka Belajar-Kampus Merdeka". Kebijakan Merdeka Belajar-Kampus Merdeka yang diluncurkan oleh Menteri Pendidikan dan Kebudayaan merupakan kerangka untuk menyiapkan mahasiswa menjadi sarjana yang tangguh, relevan dengan kebutuhan zaman, dan siap menjadi pemimpin dengan semangat kebangsaan yang tinggi (Direktur Jenderal Pendidikan Tinggi, 2020).

Sejak hadirnya wabah Covid-19 di Indonesia, ruang gerak pendidikan semakin sempit karena banyak sekolah dan perguruan tinggi ditutup. Kebijakan ini tidak lain untuk mencegah penyebaran Covid-19 sesuai dengan edaran Direktorat Jenderal Pendidikan Tinggi Kementerian Pendidikan dan Kebudayaan Republik Indonesia Nomor 1 Tahun 2020 tentang Pencegahan Penyebaran Corona Virus Disease (Covid-19) di Perguruan Tinggi.

Berdasarkan hasil evaluasi pembelajaran di Universitas Muhammadiyah Bangka Belitung pada matakuliah Kewirausahaan tahun akademik 2020/2021, sejak hadirnya pandemi Covid19 pembelajaran dilakukan secara virtual atau daring. Capaian pembelajaran matakuliah tersebut diharapkan mahasiswa mampu membuat sebuah usaha yang dilakukan secara virtual dengan memanfaatkan media sosial. Keterbatasan ruang pembelajaran yang seharusnya mahasiswa dapat berpraktik langsung harus dialihmediakan. Oleh karena itu, perlu adanya perubahan sikap, cara berpikir dan berkomunikasi mahasiswa agar capaian pembelajaran dapat tercapai.

Matakuliah Kewirausahaan merupakan salah satu pembelajaran yang sangat strategis dalam mewujudkan cita-cita pemerintah. Mahasiswa dibekali kemampuan berwirausaha sejak dini hingga pada masanya ia bekerja mampu menyesuaikan dengan perkembangan zamannya. Tantangan dan tuntutan perubahan yang terjadi dalam perkembangan dunia 
pendidikan mutakhir menuntut penyesuaian (adjustment) pada banyak aspek penyelenggaraan pendidikan (Maulina Hendrik \& Martahayu, 2018).

Berwirausaha secara daring di berbagai media sosial merupakan alternatif solusi di saat negara Indonesia lumpuh di berbagai sektor seperti di bidang perekonomian, pendidikan, sosial budaya, dan bidang lainnya. Hadirnya pandemi Covid-19 telah menelan 142.000 jiwa dari 4,22 juta kasus hingga Oktober 2021. Salah satu kelebihan berwirausaha secara daring di kondisi saat ini adalah mengurangi kontak secara langsung antara pembeli. Sebaliknya, juga dapat memberikan kekurangan bagi kedua belak pihak dari bentuk komunikasi yang terjadi. Apabila komunikasi yang terjadi tidak terjalin atau terjadi ketidaksantunan berbahasa maka transaksi akan gagal. Pranowo mengemukakan beberapa faktor penyebab pemakaian bahasa yang tidak santun: 1) penutur tidak mengetahui kaidah kesantunan yang harus digunakan, (2) penutur memperoleh kesantunan, (3) penutur terbiasa dalam budaya bahasa ibu, (4) gawan bayi, artinya sifat alamiah penutur yang gemar bertutur kurang santun di depan publik (Tipa Uswatun et al., 2020).

Media sosial sebagai sarana pergaulan sosial menghubungkan penggunanya dapat berkomunikasi, berinteraksi, berbagi, menambah jejaring, dan kegiatan lainnya (Rostikawati, 2020). Kerja sama dan berkomunikasi merupakan kompetensi yang diharapkan dalam berwirausaha secara virtual. Agar terjalin kerja sama yang baik dibutuhkan kemampuan berkomunikasi yang baik pula. Kesantunan seseorang dapat dilihat salah satunya dari caranya berkomunikasi. Sebaliknya, jika seseorang berbahasa tidak baik maka sudah dipastikan seseorang tersebut tidak santun. Oleh karena itu, dalam berkomunikasi baik taap muka maupun secara virtual harus memperhatikan penggunaan kosakata dengan baik.

Yus mengatakan proses komunikasi virtual memiliki gaya percakapan yang khusus. Komunikasi virtual melibatkan media verbal (seperti: lelucon, empati, saran, dan lainnya) maupun visual (seperti: senyuman) (Fallianda, 2018). Prinsip-prinsip kesantunan berbahasa dalam berkomunikasi virtual menjadi sangat penting. Tidak adanya media bertatap muka dapat menyebabkan berkurangnya usaha penutur untuk memperhatikan muka setiap lawan tutur. Leech menyatakan bahwa dalam bertindak tutur mempertimbangkan lima aspek situasi tutur, yaitu penutur dan mitra tutur, konteks tuturan, tujuan tuturan, tindak tutur sebagai bentuk tindakan atau aktivitas, dan tuturan sebagai tindak verbal (Evi Chamalah dan Turahmat, 2016). Austin membedakan jenis tindak tutur yaitu tindak tutur lokusi, tindak tutur ilokusi, dan tindak tutur perlokusi. Tindak lokusi adalah tindak mengucapkan sesuatu dengan makna kata dan makna kalimat sesuai dengan makna kata sebenarnya. Hal yang ditekankan dalam tindak ujar ini adalah makna ujaran. Tindak yang kedua yaitu tindak ilokusi. Hal yang dibicarakan di dalam tindak ujar ini adalah tentang maksud, fungsi, atau daya ujaran. Tindak tutur ketiga adalah tindak perlokusi. Tindak tutur perlokusi ini mengacu ke efek yang timbul setelah penutur menuturkan sesuatu (Maulina Hendrik, 2017).

Pemilihan diksi menjadi penentu dalam kesantunan berbahasa. Leech (Bahantwelu, 2019) membuat penanda yang dijadikan penentu santun tidaknya pemakaian bahasa, yakni maksim kebijaksanaan, maksim kedermawanan, maksim pujian, maksim kerendahan hati, maksim kesepakatan, dan maksim kesimpatian. Lebih lanjut Leech menyatakan penanda kesantunan berbahasa terbagi menjadi 6 maksim, yaitu: Pertama, maksim kebijaksanaan. Maksim ini dituntut untuk membuat sekecil mungkin kerugian bagi orang lain dan membuat keuntungan sebesar mungkin. Artinya, penutur harus memberikan tuturan yang menyenangkan hati mitra 
tutur. Dimensi yang ditunjukkan dalam maksim ini adalah dimensi orang lain bukan diri sendiri.

Kedua, maksim kedermawanan. Maksim ini mengharuskan penutur untuk memaksimalkan kerugian diri sendiri dan meminimalkan keuntungan diri sendiri. Maksim kedermawanan berpusat pada diri sendiri. Penutur berusaha membuat dirinya melakukan sesuatu yang dikatakan mitra tutur, sekalipun apa yang dikatakan tersebut dipandang sulit untuk dilakukan. Ketiga, maksim pujian. Maksim ini mengharuskan penutur memaksimalkan pujian kepada orang lain dan meminimalkan kecaman terhadap orang lain. Kata kunci maksim ini adalah tidak mengatakan hal-hal yang tidak menyenangkan mengenai orang lain.

Keempat, maksim kerendahan hati. Leech mengatakan, "Maksim kerendahan hati mengharuskan penutur untuk meminimalkan pujian kepada dirinya sendiri, tetapi harus mengecam diri sendiri sebanyak mungkin. Kelima, maksim kesepakatan. Maksim ini mengharuskan penutur memaksimalkan kesepakatan dengan orang lain dan meminimalkan ketidaksepakatan dengan orang lain. Artinya, antara penutur dengan mitra tutur harus ada upaya untuk saling memaksimalkan kecocokan dan meminimalkan ketidakcocokan. Keenam, maksim kesimpatian. Maksim ini memaksimalkan rasa simpati dan meminimalkan rasa antipati di antara penutur dan mitra tutur (Evi Chamalah dan Turahmat, 2016).

Selain itu, dalam bertutur juga memperhatikan fungsi kesantunan berbahasa. Komunikasi akan berjalan lancar apabila penanda dan fungsi kesantunan berbahasa diterapkan dengan baik. Fungsi kesantunan berbahasa tidak hanya digunakan untuk menyampaikan informasi, tetapi juga digunakan untuk membangun dan membina relasi. Rahardi membagi fungsi kesantunan berbahasa menjadi 4 fungsi (Bahantwelu, 2019), yaitu 1) Fungsi menyatakan (deklaratif). Fungsi ini tersusun dalam bentuk kalimat deklaratif, yaitu kalimat yang menyampaikan keadaan di sekeliling penutur. Pada fungsi ini penutur tidak mengharapkan adanya komentar dari lawan tutur. 2) Fungsi menanyakan (interogatif). Tuturan dengan fungsi menanyakan menggunakan kalimat interogatif atau kalimat pertanyaan. 3) Fungsi memerintah (imperatif). Fungsi ini mengandung maksud perintah atau imperatif. Kalimat imperatif dalam bahasa Indonesia dapat berupa suruhan yang sangat keras atau kasar atau suruhan yang sangat halus atau santun. 4) Fungsi eksklamatif. Fungsi ini untuk menyatakan kekaguman. Penutur dituntut untuk menyatakan kekagumannya kepada mitra tutur agar tercipta komunikasi yang baik.

Berdasarkan hasil penelitian terdahulu yang telah dilakukan (Maulidi, 2015) bahwa status pengguna media Facebook mengandung kesantunan. Bentuk kesantunan terwujud dalam data tuturan yang mengandung rasa syukur, harapan, permohonan, pertanyaan, terima kasih, penghargaan, ajakan, penawaran, dan informasi. Bentuk kesantunan yang ditemukan bervariasi. Terjadinya perbedaan itu dipengaruhi oleh faktor penutur, mitra tutur, pokok pembicaraan, suasana bicara dan tujuan tuturan. Pada penelitian ini melihat secara global pada pengguna facebook sedangkan penelitian yang telah dilakukan dibatasi pada mahasiswa yang berwirausaha secara daring di media sosial.

Berdasarkan latar belakang tersebut, penelitian ini bertujuan untuk mendeskripsikan: 1) penanda kesantunan berbahasa mahasiswa PGSD di media sosial dalam berwirausaha; 2) fungsi kesantunan berbahasa berdasarkan konteks berwirausaha mahasiswa PGSD di media sosial. 


\section{Metode Penelitian}

Penelitian ini menggunakan metode penelitian kualitatif deskriptif. Moleong mengatakan penelitian kualitatif adalah jenis penelitian yang dimaksudkan untuk memahami fenomena tentang apa yang dialami oleh subjek penelitian (Angela \& Winduwati, 2020). Oleh karena itu, penelitian kualitatif deskriptif dalam penelitian ini adalah penelitian yang mendeskripsikan penanda kesantunan dan fungsi kesantunan berbahasa dalam berwirausaha di media sosial pada mahasiswa PGSD Universitas Muhammadiyah Bangka Belitung tahun 2020. Penelitian ini dilaksanakan selama 8 bulan sejak Februari-September 2021.

Sumber data penelitian ini merupakan rekam jejak hasil pembelajaran mata kuliah Kewirausahaan semester ganjil tahun akademik 2020/2021 berupa tuturan-tuturan mahasiswa PGSD yang terdapat pada Whatsapp, Instagram. Penelitian ini menggunakan teknik pengumpulan data berupa teknik wawancara dan teknik catat. Teknik wawancara digunakan untuk memperoleh informasi tentang praktik berwirausaha di media sosial. Wawancara dilakukan terhadap dosen pengampu mata kuliah Kewirausahaan dengan jenis wawancara semiterstruktur. Teknik catat merupakan teknik untuk mencatat data yang diperoleh dari sumber data. Pada teknik ini, peneliti menyiapkan kartu data yang digunakan untuk mencatat tuturan-tuturan yang mengandung penanda kesantunan dan fungsi kesantunan berbahasa.

Teknik analisis data menggunakan analisis deskriptif yaitu mendeskripsikan objek atau sumber data yang terkumpul sebagaimana adanya. Data yang terkumpul dianalisis dengan alur: mengidentifikasi data, mengklasifikasi data, menginterpretasi data, dan melaporkan (Maulidi, 2015).

\section{Hasil dan Pembahasan}

1. Penanda Kesantunan Berbahasa Mahasiswa PGSD di Media Sosial dalam Berwirausaha Berdasarkan hasil pengumpulan dan analisis data, ditemukan empat penanda kesantuan berbahasa, yaitu pemilihan kata sesuai dengan situasi dan kondisi, menanggapi komentar dari mitra tutur dengan rendah hati, respons yang positif terhadap mitra tutur, menerima masukan dari mitra tutur. Keempat penanda tersebut diklasifikasikan menjadi maksim kebijaksanaan, maksim kedermawanan, maksim kerendahan hati, dan maksim kesepakatan.

\section{a. Penanda Maksim Kebijaksanaan}

Maksim ini dituntut untuk membuat sekecil mungkin kerugian bagi orang lain dan membuat keuntungan sebesar mungkin. Artinya, penutur harus memberikan tuturan yang menyenangkan hati mitra tutur. Dimensi yang ditunjukkan dalam maksim ini adalah dimensi orang lain bukan diri sendiri. Dalam berwirausaha secara daring, maksim ini sering ditemukan, di antaranya interaksi antara mahasiswa (pemberi jasa) dengan mitra tutur dalam percakapan berikut.

Percakapan 1

penutur : "Pecinta keripik hidroponik, hari ini tersedia berbagai jenis keripik yang tentunya sangat renyah di lidah dan kenyang di perut. Yuk, jadikan dirimu bagian dari orang yang beruntung pada hari ini."

Mitra tutur: "Pembeli pertama bonusnya apa nih?" 
Penutur : "Tenang saja, pembeli pertama dengan minimal pembelian 2 bungkus akan mendapatkan bonus 1 bungkus."

Percakapan 2

penutur : "Kami solusi terbaik Anda yang ingin menghafal Al-Qur'an one day one juz."

Mitra tutur: "bagaimana mendaftarnya ukhti?"

Penutur : "Caranya sangat mudah sekali. Bapak cukup duduk di rumah dan mainkan aplikasi e-Tahfidz, ikuti petunjuk-petunjuknya."

Berdasarkan data percakapan 1, penutur (mahasiswa penjual produk) bertujuan menawarkan produk keripiknya kepada masyarakat. Dalam tuturannya, penutur berusaha menyenangkan hati mitra tutur dengan memberikan bonus produk kepada pembeli minimal 2 bungkus keripik. Penutur memberikan harapan yang besar kepada mitra tutur bahwa keripik hidroponiknya tersedia dengan jenis sayuran yang lengkap. Hal tersebut mengartikan penutur berusaha memberikan penawaran yang terbaik bagi pembeli. Selama percakapan, bahasa yang digunakan sangat santun sehingga banyak pengguna instagram yang memberikan pertanyaan dan berminat untuk membelinya.

Selanjutnya, percakapan 2, penutur merupakan mahasiswa yang berwirausaha di bidang jasa yaitu menawarkan jasa menghafal Al-qur'an 1 hari 1 juz dengan teknik yang mudah dan efektif. Tentu, para pengguna instagram tertarik dengan tawaran yang diberikan. Selain itu, penutur memberikan kebahagiaan bagi mitra tutur, tidak perlu keluar rumah untuk mendaftar cukup duduk di rumah dan buka aplikasi e-tahfidz. Akses pengguna yang diberikan sangat mudah membuat konsumen merasa terbantukan karena dapat menghemat waktu.

Berdasarkan data tersebut dapat disimpulkan bahwa percakapan 1 dan percakapan 2 telah mematuhi prinsip kesantunan Leech khususnya maksim kebijaksanaan, yaitu penutur telah memberikan tuturan yang menyenangkan hati bagi mitra tutur.

\section{b. Penanda Maksim Kedermawanan}

Dermawan berarti pemurah hati, orang yang suka berderma. Bila dilihat dari pemaknaan kata tersebut, dapat dipastikan proses komunikasi dapat berjalan dengan baik, karena kedua tuturan saling menjaga hati. Maksim ini mengharuskan penutur untuk memaksimalkan kerugian diri sendiri dan meminimalkan keuntungan diri sendiri. Maksim kedermawanan berpusat pada diri sendiri. Penutur berusaha membuat dirinya melakukan sesuatu yang dikatakan mitra tutur, sekalipun apa yang dikatakan tersebut dipandang sulit untuk dilakukan. Dalam berwirausaha secara daring, maksim ini dapat ditemukan dalam percakapan berikut.

Percakapan 3

Penutur : "Tersedia jilbab segiempat bahan katun rayon dengan berbagai warna dan motif. Mari merapat."

Mitra tutur : "Mbak, apakah masih ada pilihan warna dan motif lainnya?"

Penutur : "Mbak mau warna apa selain yang di sini? Saya coba lihat stoknya dulu."

Mitra tutur : "Kuning keoren-orenan. Kalau ada mau pesan 5 pcs untuk seragaman."

Penutur : :Masyaallah. Saya carikan dulu ya, nanti saya chat Mbaknya kembali." 


\section{Percakapan 4}

Penutur : "Dijual udang Paname. Kualitas terjamin, harga terjangkau. Daerah jual Koba, Bangka Tengah. Siap antar semua lokasi."

Mitra tutur : "Berapa sekilonya?"

Penutur : " $1 \mathrm{~kg}$ hanya Rp150.000,-saja., beli 3 kg diskon Rp20.000,-."

Mitra tutur : "Saya mau $10 \mathrm{~kg}$ tapi minta diantar ke Sungaiselan, bisa?"

Penutur : : "Insyaallah. Saya usahakan hari ini diantar ke lokasi."

Berdasarkan tuturan dalam percakapan 3 di atas, penutur menawarkan produknya yang tersedia yaitu jilbab segiempat berbahan katun rayon dengan varian warna dan motif di dinding instagram. Penawaran tersebut direspons oleh beberapa pengguna instagram (followers). Namun, di percakapan mereka, si pembeli ingin warna dan motif yang lain dari yang dipamerkan di halaman instagram si penutur. Penutur berusaha mengakomodir permintaan si pembeli meskipun penutur kelihatan sedikit kesulitan mencari keinginan si pembeli karena dia harus mengecek stok di gudang. Gudang tersebut jauh dari jangkauannya. Tidak ingin mengecewakan pelanggan, si penutur berkorban memberikan yang terbaik. Penutur yang mematuhi maksim ini akan dianggap sebagai orang yang tahu sopan santun dan pintar menghargai orang lain. Terlihat pada tuturan "Saya carikan dulu ya, nanti saya chat Mbaknya kembali." Tuturan tersebut mengartikan penutur tidak memikirkan keuntungan yang diperoleh namun yang terpenting pembeli dilayani dengan baik.

Sama halnya dengan percakapan 4. Penutur adalah penjual udang Paname. Tuturannya yang terdokumentasi terlihat si penutur berusaha menawarkan dagangannya dengan kualitas yang baik dan harga terjangkau. Hal ini mengartikan penutur ingin memberikan yang terbaik bagi orang-orang yang hobi udang Paname. Jika ditelusuri harga udang tersebut, penutur menjual udang dengan harga yang sangat murah dibandingkan penjual udang lainnya, bahkan untuk pemesanan yang tidak dapat diambil langsung, penutur siap menghantarkan ke lokasi pembeli. Selain itu, harga yang diberikan untuk pembelian lebih dari $3 \mathrm{~kg}$ akan mendapatkan potongan harga Rp20.000,-. Melihat situasi percakapan tersebut, si penutur sangat merugikan diri sendiri. Padahal penutur dapat menjual harga udang sama halnya dengan penjual lainnya, sehingga mendapatkan keuntungan yang besar bagi dirinya. Namun, niat penutur tidak seperti yang dipikirkan banyak orang. Niatnya dapat membuat konsumen puas atas dagangannya.

Berdasarkan kedua percakapan di atas, dapat disimpulkan penutur telah mematuhi prinsip kesantunan Leech khususnya maksim dermawan, membuat keuntungan diri sendiri sekecil mungkin dan membuat kerugian diri sendiri sebesar mungkin.

\section{c. Penanda Maksim Kerendahan Hati}

Leech (Bahantwelu, 2019) mengatakan, "Maksim kerendahan hati mengharuskan penutur untuk meminimalkan pujian kepada dirinya sendiri, tetapi harus mengecam diri sendiri sebanyak mungkin." Orang yang dapat mematuhi maksim ini disebut sebagai orang yang rendah hati dan tidak sombong. Dalam pembelajaran mata kuliah Kewirausahaan, mahasiswa dibekali materi kemampuan berkomunikasi. Materi ini bertujuan untuk memberikan pemahaman kepada mahasiswa sebagai calon pengusaha yang sukses bahwa menjadi pengusaha harus rendah hati, tidak mengunggulkan diri sendiri karena dapat disebut sebagai orang yang tidak santun dan sombong. Sementara itu, sebagai pengusaha harus melayani 
pembeli sebaik mungkin. Dalam berwirausaha secara daring, maksim ini dapat ditemukan dalam percakapan berikut.

Percakapan 5

Penutur : "Dijual udang Paname. Kualitas terjamin, harga terjangkau. Daerah jual Koba, Bangka Tengah. Siap antar semua lokasi."

Mitra tutur : "Berapa sekilonya?"

Penutur : " $1 \mathrm{~kg}$ hanya Rp150.000,-saja., beli 3 kg diskon Rp20.000,-."

Mitra tutur : "Saya mau $10 \mathrm{~kg}$ tapi minta diantar ke Sungaiselan, bisa?"

Penutur : "Insyaallah. Saya usahakan hari ini diantar ke lokasi."

Mitra tutur : "alhamdulillah. Baru ini ada penjual yang mau mengantarkan sampai ke rumah dan sangat jauh dengan harga yang sama."

Penutur : "Oh jangan begitu, Ibu. Biasa saja. Saya berusaha saja untuk memenuhi keinginan pembeli termasuk ibu."

Percakapan 6

Penutur : "Kami solusi terbaik Anda yang ingin menghafal Al-Qur'an one day one juz."

Mitra tutur : "bagaimana mendaftarnya ukhti?"

Penutur : "Caranya sangat mudah sekali. Bapak cukup duduk di rumah dan mainkan aplikasi e-Tahfidz, ikuti petunjuk-petunjuknya."

Mitra tutur : "kalau sudah mendaftar, kapan saya bisa bergabung? Saya sudah tidak sabar lagi ingin diajarkan hafalan di sini karena informasi dari teman saya suara ustadzahnya merdu dan baik-baik."

Penutur : "Segera Kakak. Kakak tidak perlu berlebihan memuji. Kelebihan itu datangnya dari Allah Swt., semua umat-Nya pasti diberikan kelebihan dan kekurangan. Semangat ya Kakak hafalannya."

Berdasarkan tuturan pada percakapan 5, penutur sebagai penjual udang Paname terkenal dengan dagangannya yang murah berkualitas. Perbandingan harga yang sangat jauh dengan penjual udang lainnya dan udang yang dijual adalah udang segar membuat pembeli berlangganan padanya. Selain itu, pembeli juga merasa dimudahkan untuk menikmati udang Paname karena pembeli tidak perlu ke luar rumah cukup menunggu pesanan udangnya diantarkan ke rumah tanpa ada perbedaan harga kecuali jasa kirim. Di sela-sela percakapannya, pembeli berusaha memuji penjual udang, "Alhamdulillah. Baru ini ada penjual yang mau mengantarkan sampai ke rumah dan sangat jauh dengan harga yang sama." Penjual merespons, "Oh jangan begitu, Ibu. Biasa saja. Saya berusaha saja untuk memenuhi keinginan pembeli termasuk ibu."Hal tersebut tampak jelas penutur mematuhi maksim kerendahan hati yaitu penutur meminimalkan pujian-pujian terhadapnya.

Sama halnya dengan tuturan pada percakapan 6, penutur yang menawarkan jasa menghafal al-qur'an telah mematuhi maksim kerendahan hati yang terlihat jelas dari tuturannya, "Segera Kakak. Kakak tidak perlu berlebihan memuji. Kelebihan itu datangnya dari Allah Swt., semua umat-Nya pasti diberikan kelebihan dan kekurangan. Semangat ya Kakak hafalannya." Tuturan tersebut diucapkan karena mitra tutur memujinya, "....Saya sudah tidak sabar lagi ingin diajarkan hafalan di sini karena informasi dari teman saya suara ustadzahnya merdu dan baik-baik." 


\section{d. Penanda Maksim Kesepakatan}

Maksim ini mengharuskan penutur memaksimalkan kesepakatan dengan orang lain dan meminimalkan ketidaksepakatan dengan orang lain. Artinya, antara penutur dengan mitra tutur harus ada upaya untuk saling memaksimalkan kecocokan dan meminimalkan ketidakcocokan, misalnya saat terjadi komunikasi antara penutur dan mitra tutur terjadi pemahaman yang berbeda, diharapkan tidak terjadi konfrontasi, tetap harmonis hingga terjadinya kesepakatan. Percakapan kedua belak pihak dikatakan baik bila tidak terjadi konflik. Dalam berwirausaha secara daring, maksim ini dapat ditemukan dalam percakapan berikut.

Percakapan 7

Penutur : "Dijual udang Paname. Kualitas terjamin, harga terjangkau. Daerah jual Koba, Bangka Tengah. Siap antar semua lokasi."

Mitra tutur : "Berapa sekilonya?"

Penutur : " $1 \mathrm{~kg}$ hanya Rp150.000,-saja., beli 3 kg diskon Rp20.000,-."

Mitra tutur : "Saya mau $10 \mathrm{~kg}$ tapi minta diantar ke Sungaiselan, bisa?"

Penutur : "Insyaallah. Saya usahakan hari ini diantar ke lokasi."

Percakapan 8

penutur : "Pecinta keripik hidroponik, hari ini tersedia berbagai jenis keripik yang tentunya sangat renyah di lidah dan kenyang di perut. Yuk, jadikan dirimu bagian dari orang yang beruntung pada hari ini."

Mitra tutur : "Pembeli pertama bonusnya apa nih?"

Penutur : "Tenang saja, pembeli pertama dengan minimal pembelian 2 bungkus akan mendapatkan bonus 1 bungkus."

Mitra tutur : "Saya mau 4 bungkus ya."

Berdasarkan percakapan 7, penutur menawarkan udang Paname ke pembeli melalui media instagram. Dalam percakapannya terjadi akad transaksi jual beli atau terjadinya kesepakatan $\mathrm{d}$ antara pembeli dan penjual. Pembeli ingin membeli udang $10 \mathrm{~kg}$ dan di antar ke Sungaiselan. Keinginan pembeli disepakati penjual yang akan mengantarkan udang ke lokasi. Kesepakatan yang terjadi tidak melalu diskusi yang panjang. Dalam waktu yang singkat terjadi transaksi di antara penjual dan pembeli.

Begitu pula pada percakapan 8, penutur menawarkan keripik hidroponik. Lalu mitra tutur sebagai calon pembeli menanyakan bonus bila membeli keripik tersebut. Dengan sigapnya, penjual langsung memberikan tawaran, "Tenang saja, pembeli pertama dengan minimal pembelian 2 bungkus akan mendapatkan bonus 1 bungkus." Lalu, disambut oleh calon pembeli, "Saya mau 4 bungkus ya." Artinya, telah terjadi kesepakatan di antara penutur dan mitra tutur dan tanpa melalui perdebatan yang panjang pula.

\section{Fungsi Kesantunan Berbahasa Berdasarkan Konteks Berwirausaha Mahasiswa PGSD di Media Sosial}

Berdasarkan hasil pengumpulan data, ditemukan tiga fungsi kesantunan berbahasa dalam berwirausaha di media sosial pada mahasiswa PGSD Universitas Muhammadiyah Bangka 
Belitung. Fungsi kesantunan berbahasa terdiri atas fungsi menyatakan, fungsi menanyakan, dan fungsi persetujuan.

a. Fungsi menyatakan

Fungsi ini tersusun dalam bentuk kalimat deklaratif, yaitu kalimat yang menyampaikan keadaan di sekeliling penutur. Pada fungsi ini penutur tidak mengharapkan adanya komentar dari lawan tutur. Hasil temuan dalam tuturan percakapan antara penjual dan pembeli di instagram dan whatsapp:

1) "Pecinta keripik hidroponik, hari ini tersedia berbagai jenis keripik yang tentunya sangat renyah di lidah dan kenyang di perut. Yuk, jadikan dirimu bagian dari orang yang beruntung pada hari ini." Dalam konteks ini penutur bermaksud menginformasikan kepada orang lain bahwa saat ini si penutur menyediakan berbagai jenis keripik yang bahan bakunya adalah sayuran hidroponik.

2) "Kami solusi terbaik Anda yang ingin menghafal Al-Qur'an one day one juz." Konteks ini memberikan infomasi kepada orang lain bahwa jika ingin menghafal al-qur'an 1 hari 1 juz, pemilik instagram adalah solusinya.

3) "Tersedia jilbab segiempat bahan katun rayon dengan berbagai warna dan motif. Mari merapat." Penutur memberikan informasi kepada pengguna instagram bahwa saat ini penutur menjual jilbab segiempat berbahan katun rayon dengan berbagai warna dan motif.

4) "Dijual udang Paname. Kualitas terjamin, harga terjangkau. Daerah jual Koba, Bangka Tengah. Siap antar semua lokasi." Penutur berusaha sebagai penjual memberikan infomasi agar produk yang dijualnya dapat dibeli.

b. Fungsi menanyakan

Pada dasarnya dalam berwirausaha tentu akan ada tanya jawab antara penjual dan pembeli hingga mencapai kesepakatan atau pun tidak. Tuturan dengan fungsi menanyakan menggunakan kalimat interogatif atau kalimat pertanyaan. Temuan dalam tuturan percakapan antara penjual dan pembeli di instagram dan whatsapp sebagai fungsi menanyakan:

1) "Pembeli pertama bonusnya apa nih?"

2) "bagaimana mendaftarnya ukhti?"

3) "Mbak, apakah masih ada pilihan warna dan motif lainnya?

4) "Saya mau $10 \mathrm{~kg}$ tapi minta diantar ke Sungaiselan, bisa?"

5) "Berapa sekilonya?"

Berdasarkan temuan tersebut, fungsi menanyakan digunakan apabila mitra tutur ingin mengetahui sesuatu yang diinformasikan penutur. Mitra tutur bertanya terhadap sesuatu yang telah diinformasikan baik secara eksplisit maupun implisit. Sebagai contoh pada tuturan 1) di atas, konteks pertanyaannya di luar dari sesuatu yang ditawarkan yaitu penutur menawarkan keripik hidroponik, sedangkan mitra tutur menanyakan bonus jika sebagai pembeli pertama. Tuturan 2), 4) dan 5), mitra tutur menanyakan informasi yang belum tersampaikan oleh penutur secara langsung. Berbeda pula dengan tuturan 3) mitra tutur tampaknya senang dengan tawaran penutur namun keinginannya tidak ada dipilihan tersebut, sehingga mitra tutur menanyakan yang tidak diinformasikan di dinding instagramnya. 


\section{c. Fungsi persetujuan}

Berdasarkan temuan dalam percakapan di ruang chat antara penjual dan pembeli, ditemukan konteks percakapan yang mengandung fungsi persetujuan:

1) "Insyaallah. Saya usahakan hari ini diantar ke lokasi."

2) "Saya mau 4 bungkus ya."

Rahardi menyatakan tuturan persetujuan adalah tuturan yang disampaikan oleh lawan tutur sebagai reaksi atas tuturan penutur. Artinya, adanya persetujuan atau kesepakatan karena terjadinya permintaan (Bahantwelu, 2019). Pada tuturan 1) terlihat bahwa penutur mengusahakan untuk mengantarkan pesanan mitra tutur. Telah terjadi kesepakatan bahwa udang Paname yang dipesan diantar ke lokasi pemesan dan penutur menyanggupinya. Begitu pula tuturan 2) mitra tutur menginginkan 4 bungkus keripik hidroponik karena penutur memberikan bonus 1 bungkus untuk setiap pembelian 2 bungkus keripik. Jika tidak ada penawaran demikian maka tidak akan terjadi kesepakatan terhadap produk yang dibeli.

\section{Kesimpulan}

Berdasarkan hasil penelitian dan pembahasan, dapat disimpulkan: 1) ditemukan empat penanda kesantuan berbahasa dalam percakapan mahasiswa dengan mitra tutur, yaitu pemilihan kata sesuai dengan situasi dan kondisi, menanggapi komentar dari mitra tutur dengan rendah hati, respons yang positif terhadap mitra tutur, menerima masukan dari mitra tutur. Keempat penanda tersebut diklasifikasikan menjadi maksim kebijaksanaan, maksim kedermawanan, maksim kerendahan hati, dan maksim kesepakatan. 2) ditemukan tiga fungsi kesantunan berbahasa dalam berwirausaha di media sosial pada mahasiswa PGSD Universitas Muhammadiyah Bangka Belitung. Fungsi kesantunan berbahasa terdiri atas fungsi menyatakan, fungsi menanyakan, dan fungsi persetujuan. Berdasarkan penelitian yang telah dilakukan, masih diperlukannya penelitian lanjutan karena pada penelitian ini peneliti dibatasi pada penanda kesantunan berbahasa dan fungsi kesantunan berbahasa yang terdapat dalam percakapan jual beli mahasiswa. Gagasan selanjutnya, penelitian kesantunan berbahasa sangat diperlukan terlebih kondisi Indonesia saat ini lebih banyak berinteraksi di dunia maya sehingga diperlukan kajian-kajian untuk mengevaluasi perkembangan bahasa di dunia maya dan kaitannya terhadap perkembangan zaman yang serba digitalisasi.

\section{Daftar Pustaka}

Angela, M., \& Winduwati, S. (2020). Representasi Kemiskinan dalam Film Korea Selatan (Analisis Semiotika Model Saussure pada Film Parasite). Koneksi, 3(2), 478. https:// doi.org/10.24912/kn.v3i2.6480

Bahantwelu. (2019). Analısıs Penanda dan Fungsı Kesantunan Berbahasa dalam Pembelajaran Bahasa Indonesia. In FKIP Universitas Sanata Darma.

Direktur Jenderal Pendidikan Tinggi. (2020). Buku panduan merdeka belajar - Kampus Merdeka. In Direktorat Jenderal Pendidikan Tinggi Kementerian Pendidikan dan Kebudayaan.

Evi Chamalah dan Turahmat. (2016). Tindak Tutur Ekspresıf pada Bak Truk sebagaı Alternatıf Materı Ajar Pragmatık. BAHASTRA, XXXV(2), 27-40. 
Fallianda. (2018). Kesantunan Berbahasa Pengguna Media Sosial Instagram: Kajıan Sosiopragmatik. Etnolingual, 2(1), 35-54. Retrieved from http://dx.doi.org/10.1053/j.gastro.2014.05.023\%0Ahttps://doi.org/10.1016/j.gie.2018.0 4.013\%0Ahttp://www.ncbi.nlm.nih.gov/pubmed/29451164\%0Ahttp://www.pubmedc entral.nih.gov/articlerender.fcgi?artid=PMC5838726\%250Ahttp://dx.doi.org/10.1016/j .gie.2013.07.022\% 250 .

Hendrik, M, \& Pramesti, D. (2021). Kerja Sama Antara Guru dengan Siswa Selama Pembelajaran Daring Di Masa Pandemi Covid-19. ... Pendidikan Dan Pembelajaran, 5, 921934. Retrieved

from http://www.journal.umtas.ac.id/index.php/naturalistic/article/view/1275

Hendrik, Maulina. (2017). SENASBASA (Seminar Nasional Bahasa dan Sastra) Edisi 1 Tahun. 186194. Retrieved from http://research-report.umm.ac.id/index.php/

Hendrik, Maulina, \& Martahayu, V. (2018). Pemahaman dan Partisipasi Guru Sekolah Dasar Dalam Menulis Karya Ilmiah. In Society. https://doi.org/10.33019/society.v6i1.61

Maulidi, A. (2015). Kesantunan Berbahasa pada Media Jejaring Sosial Facebook. E-Journal Bahasantodea, 3(4), 42-49. Retrieved from http://jurnal.untad.ac.id/jurnal/index.php/Bahasantodea/article/view/6328

Rostikawati, Y. dkk. (2020). Peran Guru dalam Membentuk Karakter Siswa Melalui Pembelajaran Kesantunan Berbahasa di Media Sosial. Abdimas Siliwangi, 03(01), 49-59.

Tipa Uswatun, A., Wijayanti, C. P., Puspitasari, M., Bahasa, P., Indonesia, S., \& Dahlan, U. A. (2020). Krisis Kesantunan Berbahasa di Media Sosial İnstagram Sebabkan Fenomena Cyberbullying. Krisis Kesantunan Berbahasa Di Media Sosial Instagram Sebabkan Fenomena Cyberbullying, 2(1), 67-73.

Yaumi, M. (2018). Media dan Teknologi Pembelajaran. In Jakarta. 